УДК: 619:616.1/4(075.8)

(C) 2014

Цвіліховський М. І., доктор біологічних наук,

Голопура С. І., кандидат ветеринарних наук

Національний університет біоресурсів і природокористування України

\title{
КОРЕКЦІЯ ВМІСТУ ЗАГАЛЬНОГО БІЛКА ТА СЕЧОВИНИ В СИРОВАТЦІ КРОВІ НОВОНАРОДЖЕНИХ ТЕЛЯТ У ПЕРІОД ФОРМУВАННЯ КОЛОСТРАЛЬНОГО ІМУНІТЕТУ
}

\section{Рецензент - доктор ветеринарних наук, професор Б. П. Киричко}

Наведені результати застосування експериментального ліпосомального макрокапсулярного препарату на основі соєвого лециитину для корекції показників вмісту загального білка та сечовини в сироватиі крові новонароджених телят у період формування колострального імунітету. Показано, що застосування препарату per os новонародженим телятам за 15-20 хвилин до згодовування їм молозива забезпечує переважання анаболічних процесів над катаболічними, профілактує виникнення розладів травлення та покращує механізми детоксикації організму в ичих тварин.

Ключові слова: колостральний імунітет, молозиво, загальний білок, сечовина, новонароджені телята.

Постановка проблеми. В організмі новонароджених тварин із часу ініціації власних процесів газообміну поступово удосконалюються механізми терморегуляції, детоксикації, травлення, регуляції кислотно-лужного та електролітного балансу й інше, що загалом забезпечується метаболічною перебудовою в тканинах. Особливе значення в адаптації новонароджених телят до позаутробного розвитку належить колостральному імунітету [1].

Аналіз основних досліджень і публікацій, у яких започатковано розв'язання проблеми. Колостральні імуноглобуліни (Ig) характеризуються високою здатністю до гемолізу, бактеріолізу, опсонізації, мають вирішальне значення в профілактиці колісепсису, а імуноглобуліни клаcy $\mathrm{G}$ мають значний нейтралізуючий вплив на токсини і віруси. Концентрація останніх у молозиві корів становить 85-90\% від усіх Ig [2-5].

Мета - дослідити показники вмісту загального білка та сечовини в сироватці крові новонароджених телят, а завдання досліджень - здійснити їх корекцію в період формування колострального імунітету у цих тварин шляхом застосування експериментального ліпосомального макрокапсулярного препарату на основі соєвого лецитину.

Матеріали і методи дослідження. Дослідження проводилися в НДГ «Великоснітинське ім. О. В. Музиченка» НУБіП України. В досліді були використані телята віком від їх народження до 11 діб. Було сформовано 2 групи телят (контрольну та дослідну) по 5 тварин у кожній. Телятам обох груп випоювали молозиво в кількості 2-х л після народження, а потім - по 1,5 л через кожні 4 години впродовж першої доби й через кожні 6 годин - на 2-у і 3-ю доби життя телят. 3 4-добового віку телят переводили на 3-разову годівлю.

Телята дослідної групи отримували per os експериментальний ліпосомальний макрокапсулярний препарат на основі соєвого лецитину в дозі 5 мл - зранку, за 15 хв до годівлі їх молозивом. Відбір крові в телят проводили 3 яремної вени у вакуумні пробірки через $6,24,72$ години та на 7-y і 11-у доби їх життя. Показники вмісту загального білка та сечовини в сироватці крові телят визначали за загальноприйнятими методами 3 використанням фотометричного біохімічного аналізатора «Lab Line 010». У проведенні біохімічних досліджень були використані реактиви фірми СпайнЛаб (США).

Результати дослідження. Низький вміст загального білка в сироватці крові телят до першого випоювання їм молозива $(43,8 \pm 1,5$ г/л) (див. табл.) пояснюється відсутністю в ній білків імуноглобулінової фракції, що не проникають через плаценту корови-матері в кров плода [6].

Після випоювання молозива рівень загального білка в сироватці крові телят контрольної групи зростав і на 3-ю добу їх житті був у 1,13 разу достовірно вищим $(\mathrm{p} \leq 0,05)$ порівняно з початком досліду, після чого залишався відносно стабільним.

Натомість у телят дослідної групи нами було встановлено достовірне зростання цього показника вже через 6 годин після народження в 1,3 разу ( $\leq 0,001)$, а на 3-ю добу життя тварин - в $1,47$ разу ( $\mathrm{p} \leq 0,001)$ (див. табл.).

Це можна пояснити більш інтенсивним всмоктуванням у тонкому кишечнику новонароджених телят Ig молозива в нативному стані за впливу ліпосомального макрокапсулярного препарату. 
ВЕТЕРИНАРНА МЕДИЦИНА

\section{Показники вмісту загального білка та сечовини у сироватці крові новонароджених телят, $M \pm m, n=5$}

\begin{tabular}{|c|c|c|c|c|}
\hline \multirow{2}{*}{$\begin{array}{c}\text { Час після наро- } \\
\text { дження теляти }\end{array}$} & \multicolumn{2}{|c|}{ Загальний білок, г/л } & \multicolumn{2}{c|}{ Сечовина, ммоль/л } \\
\cline { 2 - 5 } & контрольна група & дослідна група & контрольна група & дослідна група \\
\hline молозива & $43,8 \pm 1,5$ & $43,8 \pm 1,5$ & $4,13 \pm 0,33$ & $4,13 \pm 0,33$ \\
\hline 6 годин & $45,3 \pm 1,2$ & $56,9 \pm 1,7 * * *$ & $3,9 \pm 0,4$ & $4,03 \pm 0,49$ \\
\hline 24 години & $47,7 \pm 0,7$ & $62,4 \pm 2,5^{* * *}$ & $5,73 \pm 0,42$ & $3,57 \pm 0,28^{* *}$ \\
\hline 72 години & $49,7 \pm 0,8$ & $64,3 \pm 3,4 * *$ & $5,27 \pm 0,56$ & $2,8 \pm 0,06 * *$ \\
\hline 7 діб & $48,9 \pm 0,5$ & $63,2 \pm 1,3^{* * *}$ & $9,83 \pm 0,46$ & $7,33 \pm 0,13^{* * *}$ \\
\hline 11 діб & $47,5 \pm 0,6$ & $59,8 \pm 1,6^{* * *}$ & $11,67 \pm 0,62$ & $4,35 \pm 0,38^{* * *}$ \\
\hline
\end{tabular}

Примітка: $\mathrm{p} \leq 0,05^{*}, \mathrm{p} \leq 0,01^{* *}, \mathrm{p} \leq 0,001^{* * *}$ порівняно з контрольною групою

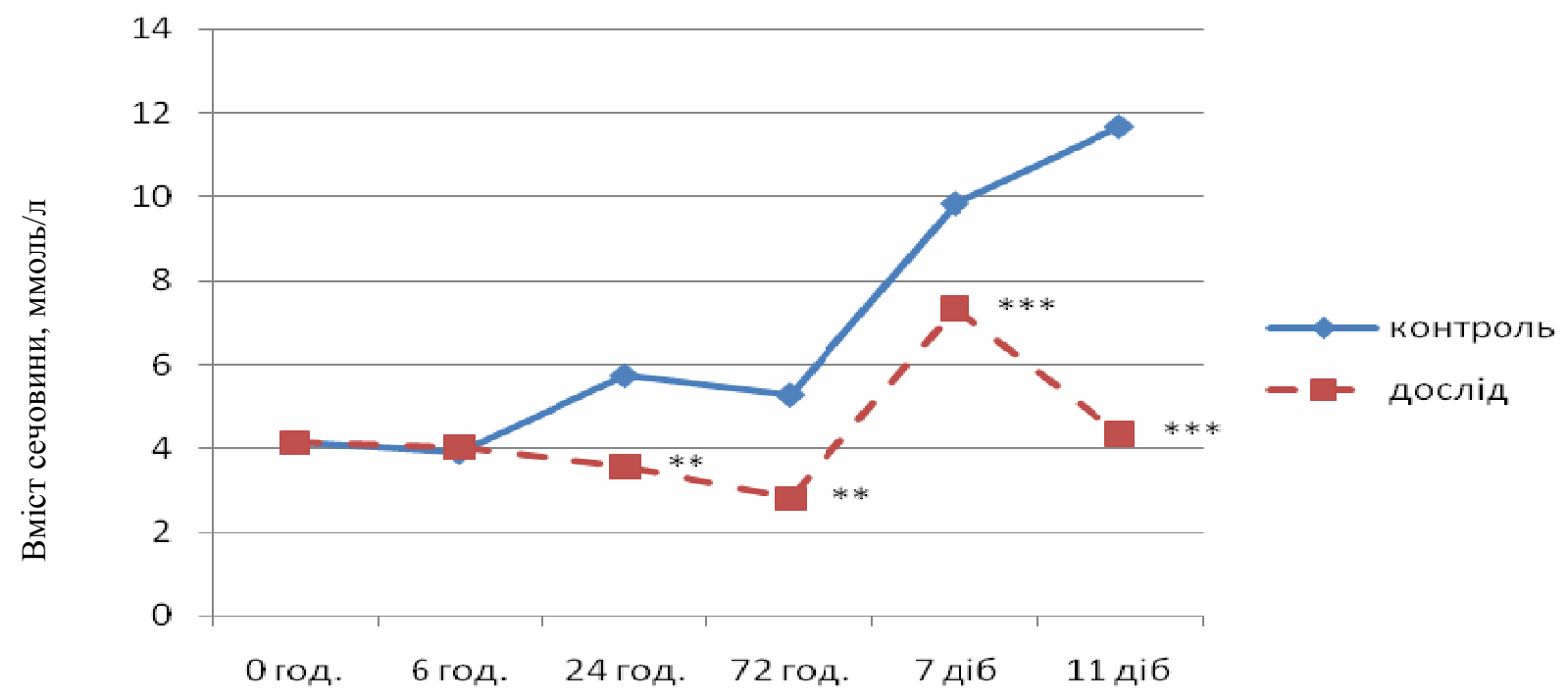

Рис. Вміст сечовини (ммоль/л) у сироватці крові новонароджених телят, $n=5$

Одночасно 3 процесами біосинтезу білків в організмі тварин відбувається процес їх розпаду, який значно посилюється за розвитку патологічних явищ. Одним із найбільш вагомих продуктів розпаду білків $\epsilon$ азот сечовини, вміст якої в сироватці крові новонароджених телят до випойки їм молозива становив 4,13 $\pm 0,33$ ммоль/л (див. табл.).

Через 24 години після народження вміст сечовини в сироватці крові телят дослідної групи порівняно $з$ контролем був вірогідно нижчим (див. рис.) у 1,38 разу $(\mathrm{p} \leq 0,01)$, а максимальна різниця становила 2,7 разу $(\mathrm{p} \leq 0,001)$ на $11-\mathrm{y}$ добу після народження тварин (див. рис.).

Однією з можливих причин недостатнього засвоєння небілкового азоту в організмі телят контрольної групи може бути низька інтенсивність реакцій трикарбонового циклу, гіпоглікемія, високий рівень процесів амонієгенезу в тканинах та явище ацидозу [6].

Залежно від вмісту загального білка, сечовини та їх співвідношення в сироватці крові телят $\epsilon$ можливість оцінити баланс азоту в їх організмі.

Так, через 24 години після народження в сироватці крові телят дослідної групи порівняно 3 контролем встановлено достовірно вищий у 1,31 разу $(\mathrm{p} \leq 0,001)$ вміст загального білка та вірогідно нижчий у 1,38 разу $(\mathrm{p} \leq 0,01)$ вміст сечовини. Подібна закономірність зберігається й через 72 години та на 7-у й 11-у доби після народження телят цієї групи: саме через 72 години та на 7-y i 11-у доби після народження в сироватці крові телят дослідної групи вміст загального білка був у $1,29(\mathrm{p} \leq 0,01), 1,29(\mathrm{p} \leq 0,001)$ та $1,25(\mathrm{p} \leq 0,001)$ рази відповідно достовірно вищим, а вміст сечовини відповідно в $1,47(\mathrm{p} \leq 0,01), 1,25(\mathrm{p} \leq 0,001)$ i $1,63(\mathrm{p} \leq 0,001)$ разів достовірно нижчим порівняно $з$ телятами контрольної групи. 


\section{ВЕТЕРИНАРНА МЕДИЦИНА}

Збільшення співвідношення загальний білок/ сечовина в організмі телят вказує на перевагу анаболічних процесів над катаболічними. Цей показник у телят контрольної групи був значно меншим порівняно 3 аналогічним у телят дослідної групи і становив через 6 годин 11,6 проти 14,1 ; через 24 години $-8,32$ проти 17,5 ; через 72 години - 9,43 проти 23,0; через 7 діб - 5,0 проти 8,6 і через 11 діб - 4,0 проти 13,7 відповідно.

Таким чином, застосування експериментального ліпосомального макрокапсулярного препарату на основі соєвого лецитину новонародженим телятам дослідної групи вказує на значну перевагу анаболічних процесів над катаболічними у цих тварин порівняно з телятами контрольної групи.

Зазначимо, що впродовж досліду в телят контрольної групи, починаючи 3 другої і до 11-ї діб життя, спостерігали розлади травлення, що супроводжувалися діареєю, дегідратацією організму, пригніченням тварин та зниженням у них апетиту.

У телят дослідної групи спостерігали незначні розлади травлення, симптоми яких зникали вже на другу-третю доби від їх початку.

У зв'язку з фізіологічно високим рівнем синтезу білка в організмі новонароджених телят рівень сечовини в сироватці їх крові нижчий порівняно 3 нормою для дорослих тварин. Підвищення рівня сироваткової сечовини крові телят контрольної групи можна пояснити з її посиленим синтезом внаслідок процесів дисиміляції,

\section{БІБЛІОГРАФІЯ}

1. Любеиька T. В. Особливості метаболічної адаптації телят на ранніх етапах постнатального розвитку та шляхи корекції виявлених порушень : Автореф. дис. ... доктора вет. наук: 03.00.04 / Національний аграрний університет. Київ, 2000. - 37 с.

2. Маринюк М. О. Рівень колострального імунітету і розвиток розладів травлення у новонароджених телят // М. О. Маринюк, С. І. Голопура, О. М. Якимчук [та ін.] / Ветеринарна медицина України. - 2014. - № 5 (219). - С. 21-23.

3. Мельничук Д. О. Нові дані щодо механізму формування колострального імунітету у новонароджених телят та їх застосування у ветеринарній медицині // Д. О. Мельничук, М.І.Цвіліховський, Т. В. Любецька [та ін.] / Рекомендації. обумовлених стримуванням окисно-відновних процесів у трикарбоновому циклі та розвитком енергетичного дефіциту в тканинах. Це знижує інтенсивність використання амонійного азоту в біосинтетичних процесах. Іншим фактором, що впливає на зростання рівня сечовини в сироватці крові тварин контрольної групи, $\epsilon$ зниження іiі фільтрації в нирках у результаті порушення гемодинаміки. Проте підвищення вмісту сечовини може мати й позанирковий характер, наприклад, у разі втрати рідини, посиленому розпаді білків тощо.

Отримані нами дані вказують на мембраностабілізуючу дію ліпосомального макрокапсулярного препарату на основі соєвого лецитину, що може обумовлюватися здатністю фосфоліпідів, які входять до його складу, підтримувати структуру плазмолеми ентероцитів, гепатоцитів та клітин ниркового епітелію.

\section{Висновки:}

1. Розроблений нами ліпосомальний макрокапсулярний препарат на основі соєвого лецитину позитивно впливає на обмін білків в організмі новонароджених телят, забезпечуючи перевагу анаболічних процесів над катаболічними.

2. Застосування ліпосомального макрокапсулярного препарату на основі соєвого лецитину per os новонародженим телятам за 15-20 хвилин до згодовування їм молозива профілактує виникнення в них розладів травлення та покращує механізми детоксикації організму тварин.

- К. : Вид. центр НАУ, 2001. - 12 с.

4. Godden S. Colostrum management for dairy calves / S. Godden // Veterinary Clinics of North America: Food Animal Practice. - 2008. - Vol. 24. - P. 19-39.

5. Lang B. Colostrum of the dairy calf // B. Lang // Factsheet. - 2008. - № 411/23. - P. 23-28.

6. Quigley J.D. Drewry J.J. Nutrient and immunity transfer from cow to calf pre and past calving // J. Dairy Sci. - 1998. - V. 81. - P. 27792790.

7. Sing A. K., Pandita S., Vaidya M. M., Chandra G., Kushwada R. Colostral immunoglobulins and neonatal immunity in bovine // Wayamba Jornal of Animal Science - 2011. - P. 78-84. 